\title{
SEROPREVALENCIADE PESTIVIRUS DE RUMIANTES EN OVINOS REPRODUCTORES DE UNA EMPRESA DE LA SIERRA CENTRAL DEL PERÚ
}

\author{
Seroprevalence of Ruminant Pestivirus in Breeding Sheep in the \\ Central Sierra of Peru
}

\author{
Nathalie Llancares A. ${ }^{1}$, Hermelinda Rivera G. ${ }^{1,3}$, Mariluz Arainga R. ${ }^{1}$, \\ Néstor Falcón $\mathbf{P}^{2}$
}

\section{RESUMEN}

\begin{abstract}
El objetivo del presente estudio fue determinar la frecuencia de los virus de la Diarrea Viral Bovina (VDVB) y de la Enfermedad de la Frontera (VEF) en ovinos reproductores procedentes de una empresa ovejera de la sierra central del país. Se colectaron muestras de sangre de ovinos reproductores hembras $(n=165)$ y machos $(n=165)$ aparentemente sanos, con un promedio de edad de cuatro años, y criados en forma extensiva. Los anticuerpos contra VDVB y VEF se detectaron mediante la prueba de neutralización viral. El $2.1 \pm 1.5 \%(7 / 330)$ y $28.5 \pm 4.9 \%(94 / 330)$ de ovinos reproductores tuvieron anticuerpos contra el VDVB y VEF, respectivamente, con títulos de anticuerpos de 1:2 a 1:16. Se encontró asociación significativa entre el sexo del animal y la presencia de anticuerpos contra el VEF (hembras: $53.3 \pm 7.6 \%$; machos: $3.6 \pm 2.9 \%)(\mathrm{p}<0.05)$.
\end{abstract}

Palabras clave: ovinos, pestivirus, diarrea viral bovina, enfermedad de la frontera, neutralización viral

\section{Abstract}

The aim of the present study was to determine the prevalence of Bovine Viral Diarrhea virus (BVDV) and Border Disease virus (BDV) in breeding sheep from a large cooperative farm in the central highlands of Peru. Blood samples from apparently healthy sheep of 4 years old, both sexes (female $=165$; male $=165$ ) were collected for antibodies detection against BVDV and BDV using the virus neutralisation test. The $2.1 \pm 1.5 \%(7 / 330)$ and $28.5 \pm 4.9 \%$ (94/330) of breeding sheep had antibodies against BVDV and BDV respectively, with antibodies titers of $1: 2$ and 1:16. There was significant association between sex and presence of antibodies against BDV (females: $53.3 \pm 7.6 \%$; males: $3.6 \pm 2.9 \%)(p<0.05)$.

Key words: sheep, pestivirus, bovine viral diarrhea virus, border disease virus, virus neutralisation test

\footnotetext{
${ }^{1}$ Laboratorio de Microbiología y Parasitología Veterinaria, Facultad de Medicina Veterinaria, Universidad Nacional Mayor de San Marcos, Lima

${ }^{2}$ Facultad de Veterinaria y Zootecnia, Universidad Peruana Cayetano Heredia, Lima

${ }^{3}$ E-mail: hriverag2005@yahoo.es
} 


\section{INTRODUCCIÓN}

En el Perú, el ganado ovino cumple un rol socioeconómico importante, especialmente en la zona sur y centro del país. En estas regiones, el ovino predominante en las comunidades campesinas es de tipo criollo, incluso en las pocas empresas que conservan la denominación de Sociedad Agrícola de Interés Social (SAIS). Más del 70\% de la población ovina se encuentra bajo crianza extensiva en manos de pequeños criadores, y actualmente el $25 \%$ está en manos de empresas asociativas como las SAIS, Cooperativas Agrarias de Producción, Empresas Rurales de Propiedad Social y medianos productores (Rosadio y Ameghino, 1999; MINAG, 2008).

La población ovina en el país es de alrededor de 12 millones de cabezas, y representa una importante fuente de ingresos económicos y sustento de muchas familias campesinas. La población de ovinos se ha incrementado en $24 \%$ en el periodo $1993-$ 2006, siendo Puno, Cusco, Junín y Huánuco los departamentos más representativos. Sin embargo, aún existen muchas deficiencias a nivel de manejo que se refleja en bajos índices productivos y reproductivos (MINAG, 2008)

La falta de un buen manejo sanitario propicia la presentación de infecciones parasitarias y microbianas que afectan al tracto respiratorio y reproductivo (Rosadio y Ameghino, 1999). Dentro de los agentes microbianos de mayor relevancia se encuentran los pestivirus, constituidos por el virus de la diarrea viral bovina (VDVB), ampliamente distribuido en la población bovina del país (Rivera, 2008), el virus de la enfermedad de la frontera (VEF) y el virus de la peste porcina clásica (VPPC), que afectan generalmente al ganado bovino, ovino y porcino, respectivamente; aunque las infecciones interespecies son frecuentes en caso de los rumiantes.

Las principales consecuencias de las infecciones pestivirales se presentan en las ovejas gestantes, donde se observan casos de infertilidad, abortos, natimortos, momificación fetal y el nacimiento de animales inmunotolerantes que excretan el virus persistentemente, siendo estos últimos la principal fuente de contaminación (Terpstra, 1985; Houe, 1995; Paton, 1995; Nettleton et al., 1998). Además, la infección con pestivirus cursa con leucopenia e inmunosupresión, debido a su predilección por células del sistema inmunitario, haciendo que estos animales sean susceptibles a otros patógenos (Potgieter, 1995; Thabti et al., 2002).

Se dispone de escasos estudios en el país sobre la prevalencia de pestivirus en ovinos, a pesar de ser la especie más numerosa en población dentro de los rumiantes y de ser el sustento de muchas familias campesinas. El presente estudio tuvo como objetivo determinar la frecuencia de los virus de la Diarrea Viral Bovina (DVB) y de la Enfermedad Frontera (EF) en ovinos reproductores procedentes de una empresa de la Sierra central del país a fin de contribuir al mejor conocimiento de su epidemiología.

\section{Materiales y MÉTOdos}

El estudio se realizó en una empresa ovejera de la provincia de Yauli, departamento de Junín, localizada a $4100 \mathrm{msnm}$ y en el Laboratorio de Virología de la Facultad de Medicina Veterinaria (FMV) de la Universidad Nacional Mayor de San Marcos (UNMSM), Lima.

El tamaño muestral se obtuvo a través del método no paramétrico de muestreo simple al azar utilizando una prevalencia referencial de $69.5 \%$ (Flores et al., 2010), con $95 \%$ de confianza y un error del $5 \%$ (Daniel, 1996).

La empresa ovejera no contempla la vacunación contra DVB y EF en su programa de vacunación y prevención de enferme- 
dades. Se colectaron muestras de sangre de 330 ovinos reproductores (165 machos y 165 hembras), con un promedio de edad de cuatro años, criados en forma extensiva y aparentemente sanos. Las muestras se obtuvieron por punción de la vena cefálica, utilizando el sistema vacutainer y se transportaron al laboratorio para la obtención del suero por centrifugación (800 g x 5 min). Los sueros se almacenaron a $-20^{\circ} \mathrm{C}$.

La detección de anticuerpos se efectuó mediante la prueba de neutralización viral, siguiendo el protocolo descrito en el manual de la OIE (2008). La cepa Singer prototipo del biotipo $\mathrm{CP}$, con un título de $10^{-5} \mathrm{DI}_{50} \mathrm{CC} /$ $50 \mu 1$ y la cepa Cosby del VEF con $10^{-5} \mathrm{DI}_{50}$ $\mathrm{CC} / 50 \mu 1$ fueron utilizadas como antígenos y células de cornete nasal de feto bovino (CNB) libre de VDVB como sistema indicador de la prueba. Los sueros con títulos iguales o mayores a 1:2 fueron considerados positivos a anticuerpos contra VDVB y VEF.

La seroprevalencia del VDVB y del VEF fue expresada en porcentaje e intervalo de confianza (Daniel, 1996). La asociación entre la variables sexo y presencia de anticuerpos fue analizada mediante la prueba de Chi cuadrado.

\section{Resultados}

La frecuencia de VDVB y VEF en la población ovina fue de $2.1 \pm 1.5 \%$ (7/330) y $28.5 \pm 4.9 \%$ (94/330), respectivamente (Cuadro 1). Los títulos de anticuerpos contra ambos pestivirus estuvieron en un rango de 1:2 a 1:16 (Cuadros 2 y 3 ).

La frecuencia del VDVB y VEF en las ovejas reproductoras fue $3.0 \pm 2.6 \%$ y 53.3 $\pm 7.6 \%$, respectivamente (Cuadro 1), con títulos de anticuerpos en un rango de 1:2 a 1:4 contra VDVB y de 1:2 a 1:16 contra VEF (Cuadro 2). Asimismo, la frecuencia del VDVB y VEF en los reproductores machos fue de $1.2 \pm 1.7 \%$ y $3.6 \pm 2.9 \%$, respectivamente (Cuadro 1), con títulos de anticuerpos de 1:2 a 1:4 (Cuadro 3); encontrándose asociación significativa entre el sexo del animal y la presencia de anticuerpos contra el VEF $(\mathrm{p}<0.05)$.

\section{Discusión}

Los títulos de anticuerpos contra VDVB $(2.1 \pm 1.5 \%)$ y EF $(28.5 \pm 4.9 \%)$ implican que los animales estuvieron o se encuentran infectados con cepas de campo de ambos pestivirus, ya que la empresa no utiliza la vacunación contra estas enfermedades como medida de prevención. Estos resultados se suman a otros resultados serológicos realizados en ovinos del país que demuestran que los pestivirus DVB y EF están presentes en la población ovina del centro y sur del país (Alvarez et al., 2002; Flores et al., 2010). Asimismo, y como valor de comparación, se reconoce una prevalencia de 5 a $50 \%$ a nivel mundial (Nettleton et al., 1998).

La menor frecuencia del VDVB en relación al VEF sugiere que el primero no está activo en la población de ovinos reproductores estudiados, a pesar de la alta prevalencia de este virus en bovinos del valle del Mantaro (Contreras et al., 2000; Rivera et al., 2002). Los anticuerpos detectados contra el VDVB parecería que fueran producto de una infección antigua o muy reciente, y para elucidar esta última posibilidad hubiese sido necesario realizar una segunda prueba a estos mismos animales para observar la dinámica de los anticuerpos. Las reacciones cruzadas entre ambos virus son posibles por la relación antigénica entre los pestivirus (Darbyshire, 1962; Edwards, et al., 1991), pero solo siete animales tuvieron anticuerpos contra el VDVB contra 94 animales que fueron reactores al VEF (Cuadro 1), apoyando el criterio de que no se trató de reacciones cruzadas. Usualmente, la empresa importa reproductores machos de países como Chile y Australia entre otros, pudiendo estos animales haber ingresado con anticuerpos contra el VDVB, dado que las normas sanitarias del país permiten ingresar animales con anticuerpos contra el VDVB. 
Cuadro 1. Reproductores ovinos de una empresa de la Sierra Central del Perú positivos a anticuerpos contra los virus de la diarrea viral bovina (VDVB) y de la enfermedad de la frontera (VEF)

\begin{tabular}{lccc}
\hline \multirow{2}{*}{ Sexo } & \multirow{2}{*}{.$^{\circ}$} & \multicolumn{2}{c}{$\mathrm{N}^{\circ}$ de animales con anticuerpos contra: } \\
\cline { 3 - 4 } & & $\operatorname{VDVB}\left(\% \pm \mathrm{IC}^{1}\right)$ & $\operatorname{VEF}(\% \pm \mathrm{IC})$ \\
\hline Hembras & 165 & $5(3.0 \pm 2.6)$ & $88(53.3 \pm 7.6)$ \\
Machos & 165 & $2(1.2 \pm 1.7)$ & $6(3.6 \pm 2.9)$ \\
\hline Total & 330 & $7(2.1 \pm 1.5)$ & $94(28.5 \pm 4.9)$ \\
\hline
\end{tabular}

${ }^{1}$ Intervalo de confianza del 95\%

Cuadro 2. Título de anticuerpos contra los virus de la diarrea viral bovina (VDVB) y de la enfermedad de la frontera (VEF) en ovinos reproductores hembras de una empresa de la Sierra central del Perú (2008)

\begin{tabular}{lcccccc}
\hline \multirow{2}{*}{ Cepa Viral } & \multicolumn{2}{c}{ Seropositivos } & \multicolumn{4}{c}{ Inversa dilución de título de anticuerpos } \\
\cline { 2 - 7 } & $\mathrm{n} / \mathrm{N}$ & $\%$ & $2-4$ & $8-16$ & $32-64$ & $128-256$ \\
\hline VDVB & $5 / 165$ & 3.0 & 5 & 0 & 0 & 0 \\
VEF & $88 / 165$ & 53.3 & 36 & 52 & 0 & 0 \\
\hline
\end{tabular}

En un estudio similar realizado en ovinos de la misma zona, se detectó $69.5 \pm 4.4 \%$ de animales seroreactores con títulos de anticuerpos entre 2 a mayores de 256 indicando una infección activa del VDVB en el rebaño (Flores et al., 2010). En otro estudio en el sur del país en ovinos de una comunidad con crianza mixta, se detectó 13 y $15 \%$ de ovinos reactores al virus de la DVB y EF, respectivamente (Alvarez et al., 2002). Esta variada prevalencia sugiere la existencia de factores que promueven la infección, pudiendo ser uno de ellos el contacto de los ovinos con otras especies como el bovino, ya sea en forma permanente como en las crianzas mixtas, y en forma accidental como podría ocurrir en empresas que utilizan un adecuado sistema de manejo.
Los títulos de anticuerpos contra VEF no fueron mayores a 1:16 (Cuadros 2 y 3), indicando que la infección no estuvo activa en la población. La ausencia de títulos altos sugiere que no existen desafíos y que se evitan los factores estresantes, posiblemente por ser el núcleo de reproductores que se mantienen bajo un sistema adecuado de manejo. Los títulos de anticuerpos contra el VDVB no fueron mayores a 1:4 (Cuadros 2 y 3 ), apoyando la hipótesis que se trataría de anticuerpos residuales.

La mayor frecuencia de anticuerpos contra el VEF en hembras $(53.3 \pm 7.6 \%)$ comparado con los machos $(3.6 \pm 2.9 \%)$ $(\mathrm{p}<0.05)$ podría deberse al sistema de manejo más eficiente con los reproductores ma- 
Cuadro 3. Título de anticuerpos contra los virus de la diarrea viral bovina (VDVB) y enfermedad de la frontera (VEF) en ovinos reproductores machos de una empresa de la Sierra central del Perú (2008)

\begin{tabular}{lcccccc}
\hline \multirow{2}{*}{ Cepa Viral } & \multicolumn{2}{c}{ Seropositivos } & \multicolumn{4}{c}{ Inversa dilución de título de anticuerpos } \\
\cline { 2 - 7 } & $\mathrm{n} / \mathrm{N}$ & $\%$ & $2-4$ & $8-16$ & $32-64$ & $128-256$ \\
\hline VDVB & $2 / 165$ & 1.2 & 2 & 0 & 0 & 0 \\
VEF & $6 / 165$ & 3.6 & 6 & 0 & 0 & 0 \\
\hline
\end{tabular}

chos por su alto valor genético y constituir un número minoritario dentro de la población. Es importante indicar que las hembras y sus crías se mantienen separadas de los machos y sólo se juntan durante la época del empadre.

\section{Conclusiones}

Se detectaron anticuerpos contra los virus de la diarrea viral bovina $(2.1 \pm 1.5 \%)$ y enfermedad de la frontera $(28.5 \pm 4.9 \%)$ en ovinos reproductores de ambos sexos de una empresa ovejera de la sierra central del país. Los títulos de anticuerpos contra ambos virus no fueron mayores a 1:16.

\section{Literatura Citada}

1. Alvarez S, Rivera H, Pezo D, García $W$. 2002. Detección de anticuerpos contra pestivirus en rumiantes de una comunidad campesina de la provincia de Canchis, Cusco. Rev Inv Vet, Perú 13(1): 46-51.

2. Contreras G, Ståhl K, Arana C, Rivera H. 2000. Anticuerpos contra el virus de la diarrea viral bovina en muestras de leche de bovinos del valle del Mantaro (Jauja, Concepción y Huancayo). Rev Inv Vet, Perú 11(1): 58-65.

3. Daniel W. 1996. Bioestadística: Base para el análisis de las ciencias de la salud. $3^{\mathrm{a}}$ ed. México DF: Limusa. 352 p.
4. Darbyshire JH. 1962. Agar gel diffusión studies with a mucosal disease of cattle. II. A serological relationship between mucosal disease and swine fever. Res Vet Sci 3: 125-128.

5. Edwards S, Moennig V, Wensvoort G. 1991. The development of an international reference panel of monoclonal antibodies for the differentiation of hog cholera virus from other pestivirus. Vet Microbiol 29: 101-108.

6. Flores D, Rivera H, Gavidia C, Manchego A. 2010. Anticuerpos contra el virus de la diarrea viral bovina y su asociación con problemas reproductivos en borregas de una empresa ovejera de la sierra central del Perú. Rev Inv Vet, Perú 21: 113-118.

7. Houe H. 1995. Epidemiology of bovine viral diarrhea virus. Vet Clin N Am-Food A 11: 521-547.

8. [MINAG] Ministerio de Agricultura. 2008. Situación de las actividades de crianza y producción. Realidad y problemática del sector pecuario - Ovinos [Internet], [22 setiembre 2008]. Disponible en: http://www.minag.gob.pe/ situacion-de-las-actividades-de-crianzay-produccion/ovinos.html

9. Nettleton PF, Gilray JA, Dlissi E. 1998. Border disease of sheep and goats. Vet Res 29: 327-340.

10. [OIE] Organización Internacional de Epizootias. 2008. Enfermedades animales: Lista de datos por enfermedad. Enfermedad de la Diarrea Viral Bovina: Cap 
2.4.8. p 7-8. [Internet], [22 setiembre 2008]. Disponible en: http://www.oie.int/ esp/normes/mmanual/A_00131.htm

11. Paton DJ. 1995. Pestivirus diversity. J Comp Path 112: 215-236.

12. Potgieter L. 1995. Immunology of bovine viral diarrhea virus. Vet Clin N Am-Food A 11: 501-520.

13. Rivera H, Huamán $K$, Benito A, Díaz A, Arana C. 2002. Prevalencia del virus de la diarrea viral bovina y animales portadores del virus en un hato lechero del valle del Mantaro. Rev Acad Per Cienc Vet 3: 1-7.

14. Rivera H. 2008. Evolución del conocimiento sobre la enfermedad de la dia- rrea viral bovina y su agente etiológico. Rev Inv Vet, Perú 19: 93-112.

15. Rosadio R, Ameghino E. 1999. Enfermedades de los ovinos en el Perú. Pub Tec FMV No 40: 55-59.

16. Terpstra C. 1985. Border disease: a congenital infection of small ruminants. Prog Vet Microbiol Immunol 1: 175-198.

17. Thabti F, Fronzaroli L, Dlissi E, Guibert JM, Hammami S, Pepin M, Russo P. 2002. Experimental model of border disease virus infection in lambs: comparative pathogenicity of pestiviruses isolated in France and Tunisia. Vet Res 33: $35-45$. 